\title{
SISTEM SANKSI PERDAGANGAN ANAK MENURUT HUKUM ISLAM
}

\author{
Sukirno \\ Sitti Aisyah Kara \\ Jumadi \\ Pascasarjana UIN Alauddin Makassar \\ Email: inhopmii@gmail.com
}

\begin{abstract}
Abstrak: Sistem sanksi terhadap tindak pidana perdagangan anak di Indonesia dan hukum Islam, yaitu di Indonesia di atur dalam Undang-Undang No. 21 Tahun 2007 tentang Pemberantasan Tindak Pidana Perdagangan Orang dan Undang-Undang No. 23 Tahun 2002 tentang Perlindungan Anak. Sedangkan dalam hukum Islam, hukuman bagi pelaku perdagangan orang bisa termasuk jarimah hudud, qishahsh, dan ta'zir tergantung kepada akibat yang ditimbulkan terhadap korban.

Kejahatan perdagangan manusia terutama perempuan dana anak berkembang karena adanya berbagai faktor pendorong, satu diantaranya yaitu faktor kemiskinan. Masyarakat miskin yang berada di daerah-daerah terpencil dijanjikan pekerjaan yang gajinya besar mendorong anak-anak tersebut terdorong untuk mengikuti ajakan dari para pelaku. Kondisi tingkat kemiskinan tersebut semakin mudah untuk dipengaruhi dika dibarengi dengan tingkat pendidikan yang rendah. Masyarakat tidak memiliki pengetahuan yang cukup untuk menganalisis ajakan dari para pelaku yang menawarkan gaji yang besar jika tingkat pendidikan yang dimiliki oleh seseorang tersebut tidak ada.
\end{abstract}

\section{Keywords: Perdagangan Anak, Jarimah Hudud, Qishash, Ta'zir}

\section{PENDAHULUAN}

Setiap anak mempunyai harkat dan martabat yang patut dijunjungi tinggi dan setiap anak yang terlahir harus mendapatkan hak-haknya tanpa anak tersebut meminta hal ini sesuai dengan ketentuan Konvensi Hak Anak yang diratifikasi oleh Pemerintah Indonesia melalui Keputusan Presiden Nomor 36 Tahun 1990 tentang Pengesahan Convention on the Rights of The Child (Konvensi tentang Hak-hak Anak) yang mengemukakan tentang prinsip-prinsip umum perlindungan anak, yaitu non diskriminasi, kepentingan terbaik anak, kelansungan hidup dan tumbuh berkembang, dan menghargai partisipasi anak. ${ }^{1}$

Prinsip-prinsip tersebut juga terdapat di dalam ketentuan Undang-Undang Nomor 35 Tahun 2014 tentang perubahan atas Undang-Undang Nomor 23 Tahun 2002 tentang Perlindungan Anak yang dibentuk oleh pemerintah agar hak-hak anak dapat diimplementasikan di Indonesia. Kepedulian pemerintah terhadap harkat dan martabat anak sebenarnya sudah terlihat sejak 1979 ketika membuat Undang-Undang Nomor 4

\footnotetext{
2015), h. 1
}

${ }^{1}$ Rika Saraswati, Hukum Perlindungan Anak di Indoesia (Cet. II; Bandung: Citra Aditya Bakti, 
Tahun 1979 tentang Kesejahteraan Anak akan tetapi, hingga keluarnya UndangUndang Perlindungan Anak dan sampai sekarang, kesejahteraan dan pemenuhan hak anak masih jauh dari yang diharapkan. ${ }^{2}$

Setiap manusia disamping sebagai makhluk pribadi juga sebagai makhluk sosial. Manusia sebagai makhluk sosial tentunya mempunyai suatu hubungan erat ataupun memiliki keterkaitan dalam kehidupannya. Di dalam kehidupan bermasyarakat ada kalanya terjadi suatu benturan kepentingan satu dengan yang lainnya dan juga terdapat penyimpangan-penyimpangan terhadap norma-norma hukum yang yang dikenal dengan sebutan kejahatan. Kejahatan merupakan masalah sosial yang timbul di tengah-tengah masyarakat dimana pelaku dan korbannya adalah anggota masyarakat itu sendiri. ${ }^{3}$

Kejahatan di seluruh dunia selalu mengalami perkembangan yang sangat cepat sejalan dengan cepatnya kamajuan ilmu pengetahuan dan teknologi. Perkembangan mengenai masalah-masalah kejahatan, baik dilihat secara kuantitatif maupun kualitatifnya tetap memerlukan suatu pembahasan dan pengamatan sesuai dengan aktivitas permasalahannya. Tanpa mempelajari sebab-sebab terjadinya kejahatan sangat sulit untuk dimengerti alasan kejahatan itu terjadi apalagi untuk menentukan tindakan yang tepat dalam menghadapi pelaku kejahatan. ${ }^{4}$

Perdagangan (trafficking) manusia mempunyai arti yang berbeda bagi setiap orang. Perdagangan manusia meliputi sederetan masalah dan isu sensitif yang kompleks yang ditafsirkan berbeda oleh setiap orang, tergantung sudut pandang pribadi atau organisasinya. Kendati demikian, seperti yang dinyatakan oleh dua pakar perdagangan internasional, Wijers dan Lap-Chew, "...isu definisi bukanlah suatu pertanyaan akademis. Langkah yang akan diajukan untuk mencegah dan memerangi "perdagangan" dapat berbeda-beda, tergantung dari bagaimana masalah itu didefinisikan...". Isu pendefinisian ini amat penting di Indonesia karena banyak dari manifestasi perdagangan juga merupakan praktik yang diterima dalam masyarakat, sehingga mereka tidak dianggap eksploitatif, apalagi dipandang sebagai tindak perdagangan. ${ }^{5}$

Undang-Undang No. 21 Tahun 2007 tentang Tindak Pidana Perdagangan orang memberikan pengertian yaitu,

"Perdagangan Orang adalah tindakan perekrutan, pengangkutan, penampungan, pengiriman, pemindahan, atau penerimaan seseorang dengan ancaman kekerasan, penggunaan kekerasan, penculikan, penyekapan, pemalsuan, penipuan dan penyalahgunaan kekuasaan atau posisi rentan, penjeratan uang atau memberikan bayaran atau manfaat, sehingga memperoleh persetujuan dari orang yang memegang kendali atas orang lain tersebut, baik yang dilakukan di

${ }^{2}$ Rika Saraswati, Hukum Perlindungan Anak di Indoesia, h. 1

${ }^{3}$ Maidin Gultom, Perlindungan Hukum Terhadap Anak dan Perempuan (Bandung: PT Refika Aditama, 2012), h. 40.

${ }^{4}$ Maidin Gultom, Perlindungan Hukum Terhadap Anak dan Perempuan, h. 40.

${ }^{5}$ Ruth Rosenberg, Dkk, Perdagangan Perempuan dan Anak di Indonesia (Jakarta: International Catholic Migration Commission (ICMC) dan American Center for International Labor Solidarity (ACILS), 2003), h. 11. 
dalam negara maupun antar negara, untuk tujuan ekspolitasi atau mengakibatkan orang tereksploitasi."6

Di masa lalu, perdagangan dipandang sebagai pemindahan perempuan secara paksa ke luar negeri untuk tujuan prostitusi, dengan sejumlah konvensi terdahulu mengenai perdagangan hanya menfokuskan pada aspek ini. Namun kemudian perdagangan didefinisikan sebagai perpindahan manusia (khususnya perempuan dan anak), dengan atau tanpa persetujuan orang bersangkutan, di dalam suatu negara atau ke luar negeri, untuk semua bentuk perburuhan yang eksploitatif, tidak hanya prostitusi dan perbudakan yang berkedok pernikahan (servile marriage), sehingga memperluas definisi itu untuk mencakup lebih banyak isu dan jenis kekerasan. ${ }^{7}$

Berdasarkan pengalaman penculikan dan perdagangan anak yang pernah terjadi di tanah air, motif pelaku melakukan penculikan anak relatif beragam. Secara garis besar, biasanya motif yang melatarbelakangi adalah sebagai berikut:

Pertama, praktik penculikan anak yang dimanfaatkan sebagai tenaga kerja paksa, baik itu disektor industri, sebagai Tenga Kerja Indonesia (TKI), maupun sekedar dijadikan pengemis atau anak jalanan dibawah komando seorang preman yang sangar dan jahat. Di berbagai kota besar, sering terjadi anak-anak jalanan mengalami penyekapan secara halus, yakni terpaksa hidup dibawah kekuasaan dan perlindungan seorang preman dengan kompensasi menyetorkan sebagian besar penghasilan mereka mengamen atau mengemis kepada sang patron tersebut. ${ }^{8}$

Hasil pantaun dari Global Aliance Against Traffic in Women (GAATW) menemukan bahwa tak jarang anak-anak yang menjadi korban penculikan dipaksa bekerja disektor industri, pertanian atau konstruksi dengan bayaran yang rendah atau tidak dibayar sama sekali, sementara disaat yang sama mereka harus bekerja dalam kurun waktu yang lama lebih dari 12 jam atau bahkan lebih dari 15 jam per hari. Banyak dari anak-anak yang bekerja paksa ini, karena status mereka yang illegal dan tidak dimilikinya dokumen yang sah karena sudah dirampas oleh pihak pengusaha atau makelar, terpaksa menerima nasib karena ketidakberdayaan mereka. ${ }^{9}$

Kedua, praktik penculikan anak sebagai bagian dari modus kriminal untuk memperoleh uang besar dalam jangka waktu pendek. Kasus penculikan anak untuk meminta uang tebusan dari keluarga korban ini tercatat telah berkali-kali terjadi. Ketiga, kasus penculikan dan perdagangan anak untuk dijadikan korban kekerasan seksual, baik untuk dipekerjakan sebagai PSK (Pekerja Seks Komersial) maupun untuk kepentingan perbudakan yang dibungkus dengan kedok perkawinan. ${ }^{10}$

Biasanya, akibat kemiskinan, anak-anak perempuan dengan muda ditipu oleh para makelar untuk dijual kepada sejumlah lelaki di luar negeri sebagai istri yang sah,

\footnotetext{
${ }^{66}$ Tim Redaksi, Pasal 1 Undang-Undang No. 21 Tahun 2007 tentang Perdagangan Orang (Bandung: Citra Umbara, 2007), h. 3.

${ }^{7}$ Ruth Rosenberg, Dkk, Perdagangan Perempuan dan Anak di Indonesia, h. 11.

${ }^{8}$ Bagong Suyanto, Masalah Sosial Anak, (Cet. II; Jakarta: Kencana Prenada Media Group. 2013), h. 297.

${ }^{9}$ Bagong Suyanto, Masalah Sosial Anak, h. 297-298.

${ }^{10}$ Bagong Suyanto, Masalah Sosial Anak, h. 298.
} 
namun kehidupan sehari-hari mereka sebetulnya tak ubahnya seperti Pembantu Rumah Tangga (PRT) gratisan plus paksaan untuk memberikan pelayanan seksual setiap waktu. Keempat, praktik penculikan anak untuk diperjual belikan di luar negeri, baik untuk dimanfaatkan organ tubuhnya maupun untuk dijadikan anak adopsi oleh keluarga tertent $u$ yang menginginkan anak angkat. ${ }^{11}$

Secara umum Sulawesi Selatan memiliki sejarah panjang sebagai bangsa perantau. Banyak literatur yang memperlihatkan bahwa migrasi sudah merupakan bagian dari budaya suku-suku di Sulawesi Selatan, khususnya Suku Bugis dan Toraja. Informasi menarik dalam kaitannya dengan situasi trafficking di Sulawesi Selatan adalah adanya sejarah orang Sulawesi Selatan, khususnya suku Bugis Makassar sebagai pedagang budak paling tidak sejak abad ke-16, budak merupakan salah satu "komoditas" perdagangan orang Bugis Makassar. Pada awal abad 17-18 mereka menjual tawanan yang ditangkap dari pulau Nusa Tenggara, Buton, Mindanao, Sulu, dan Timur laut Kalimantan untuk dijadikan buruh perkebunan lada di Tanah Melayu, Sumatra dan sebagai pekerja di Batavia. ${ }^{12}$

Tampaknya faktor sejarah ini masih relevan dengan situasi saat ini. Perdagangan budak tampaknya kini berubah wujud dalam bentuk praktik pengiriman tenaga kerja melalui agen PJTKI. Tulisan tentang Kalimantan Timur telah memperlihatkan istilah populer yang dikenal kalangan calo di Nunukan, seperti "Bugis jual Bugis", "Tator jual Tator", dan "Jawa jual Jawa". Tampaknya, kesamaan etnis malah menjadi hal yang merugikan. Bukannya mendorong timbulnya rasa solidaritas, justru meningkatkan kerentanan dari anggota masyarakat terendah dari kelompok etnis yang bersangkutan. ${ }^{13}$

Ditinjau dari perpektif Islam bahwa konsep pengakuan dan penegakan hak-hak asasi manusia dijelaskan secara universal dan transparan dalam Al-Qur'an dan dicontohkan dalam perilaku Nabi Muhammad saw. Sebagai agama rahmatan lil alalamin, Islam menebarkan nilai-nilai kasih sayang dan kedamaian serta, mendorong manusia untuk memiliki kesadaran agar patuh, taslim, dan mampu menjalin hubungan harmonis dalam konteks huquq al-Allah dan huquq al-nas, kemampuan untuk membangun dua bentuk hubungan inilah manusia menempati posisi dan fitrahnya sebagai makhluk mulia. ${ }^{14}$

Al-Qur'an sebagai kitab suci ummat Islam telah memperingatkan kepada umat Islam bahwa manusia adalah makhluk Allah swt yang dimuliakan dan paling sempurna dari segala ciptaannya yang tidak sepantasnya untuk diperjualbelikan apapun alasannya. Olehnya itu, tulisan ini mengelaborasi lebih jauh tentang pandangan hukum Islam tentang perdagangan anak.

${ }^{11}$ Bagong Suyanto, Masalah Sosial Anak, h. 299.

${ }^{12}$ Abhijit Dasgupta, dkk, Ketika Mereka Dijual: Perdagangan Perempuan dan Anak di 15 Propinsi di Indonesia (Jakarta: ICMC Indonesia dan ACILS, 2006), h. 317.

${ }^{13}$ Abhijit Dasgupta, dkk, Ketika Mereka Dijual: Perdagangan Perempuan dan Anak di 15 Propinsi di Indonesia, h. 317.

${ }^{14}$ Mufidah Ch, Mengapa Mereka Diperdagangkan ?: Membongkar Kejahatan Traficking dalam Perspektif Islam, Hukum, dan Gender (Malang: UIN-Maliki Press, 2011), h. 65. 


\section{KAJIAN TEORITIK}

\section{a. Pengertian Perdagangan Anak}

Ada banyak rumusan kebijakan yang bisa digunakan sebagai rujukan untuk memberikan perlindungan terhadap korban perdagangan dan untuk mengantisipasi perluasan perdagangan anak. Pertama, Konvensi Hak Anak yang berisi standar internasional bagi pengakuan terhadap hakhak anak. Konvensi Hak Anak merupakan salah satu dari tujuh konvensi induk yang berkaitan dengan HAM. Menurut kajian para pemerhati hak anak, Konvensi Hak Anak merupakan konvensi internasional yang paling lengkap, karena memuat hak sipil dan politik maupun hak ekonomi, sosial dan budaya. $^{15}$

Indonesia adalah salah satu negara yang telah meratifikasi Konvensi Hak Anak. Ratifikasi ini ditetapkan dengan Keputusan Presiden (Keppres) No. 36 Tahun 1990 yang menyatakan pemberlakukan Konvensi Hak Anak di Indonesia (disertai dengan lampiran deklarasinya). Dengan demikian Indonesia memiliki konsekuensi untuk mematuhi isi Konvensi Hak Anak dan berkewajiban membuat laporan kepada PBB tentang pelaksanaan Konvensi Hak Anak di Indonesia. Selain Konvensi Hak Anak, ada beberapa dokumen rujukan lain untuk memberikan perlindungan bagi anak khususnya korban perdagangan, misalnya Concluding Observations (oleh Komite Hak Anak) atas laporan periodik I Indonesia (CRC/C/15/Add.223, 26 February 2004), Concluding Observations (oleh Komite Hak Anak) atas laporan periodik perdana Indonesia (CRC/C/15/Add.25, 24 October 1994), Sepuluh General Comment yang dikeluarkan Komite Hak Anak dalam kurun hingga Mei 2008, Rekomendasi Komite Hak Anak (1995) tentang Juvenile Justice dan Protokol Palermo

Dalam memberikan perlindungan anak, khususnya korban perdagangan, Protokol Palermo adalah salah satu dokumen yang harus menjadi rujukan. Protokol ini merupakan pelengkap dari konvensi induk "United Convention against Transnational Organized Crimes". Walaupun pemerintah Indonesia belum meratifikasi konvensi ini tetapi Indonesia sudah menandatanganinya, sehingga sudah terikat secara moral untuk melaksanakannya. ${ }^{16}$

Sedangkan kebijakan dan undang-undang di Indonesia yang menjadi rujukan dalam memberikan perlindungan terhadap anak, adalah:

a. Undang-Undang Dasar 1945,

b. Undang-Undang No.23 Tahun 2002 Tentang Perlindungan Anak,

c. Undang-Undang No.21 Tahun 2007 Tentang Pemberantasan Tindak Pidana Perdagangan Orang;

d. Peraturan Pemerintah No. 9 Tahun 2008 Tentang Mekanisme dan Tata Cara Pelayanan Terpadu untuk Korban TPPO;

e. Perpres No. 69 Tahun 2008 Tentang Subgugus Tugas Pencegahan dan Penanganan TPPO; Keputusan Presiden No.59 dari 2002 tentang Rencana Aksi Nasional untuk Penghapusan Bentuk-bentuk Terburuk Buruh Anak;

\footnotetext{
${ }^{15}$ Distia Aviandar, dkk, Analisis Situasi Hak Anak untuk Isu-isu Tertentu (Yogyakarta: Yayasan Sekretariat Anak Merdeka Indonesia, 2010), h. 56.

${ }^{16}$ Distia Aviandar, dkk, Analisis Situasi Hak Anak untuk Isu-isu Tertentu, h. 57.
} 
f. Permeneg PP No. 1 Tahun 2009 Tentang Standar Pelayanan Minimal untuk Korban TPPO;

g. Keputusan Menkokesra No. 25 Tahun 2009 Tentang Rencana Aksi Nasional Pemberantasan Tindak Pidana Perdagangan Orang (PTPPO) dan Eksploitasi Seksual Anak (ESA) 2009- 2014;

h. Kepmeneg PP No.07 Tahun 2009 Tentang Pembentukan Sekretariat Gugus Tugas PTPPO; Keputusan Ketua Harian Gugus Tugas Pusat No.8 Tahun 2009 Tentang Pembentukan Sub Gugus Tugas Pusat Pencegahan dan Penanganan Tindak Pidana Perdagangan Orang.

Kebijakan serta perundangan seperti disebutkan yang akan digunakan untuk melihat sejauh mana perlindungan terhadap anak telah diatur. Pertama, tentang definisi anak. Dalam melakukan analisis situasi perdagangan anak, pengkajian definisi anak penting dilakukan untuk memastikan hal-hal yang harus dipenuhi demi kepentingan terbaik anak. Rujukan internasional yang bisa digunakan untuk mengetahui definisi anak adalah Konvensi Hak Anak. Menurut Konvensi Hak Anak bagian I pasal 1, definisi anak adalah "Yang dimaksud dalam Konvensi sekarang ini, seorang anak adalah setiap manusia yang berusia dibawah 18 tahun kecuali, berdasarkan undangundang yang berlaku bagi anak-anak, kedewasaan dicapai lebih cepat." Definisi dalam Konvensi Hak Anak ini menjadi acuan dalam merumuskan kebijakan atau dokumen terkait lainnya, yaitu Protokol Palermo. Dalam Protokol Palero pasal 3 point (D) menyebutkan, "Anak" berarti setiap orang dibawah usia delapan belas tahun. ${ }^{17}$

Dalam berbagai undang-undang di Indonesia, sebagaimana tertuang dalam Undang-Undang No.23 Tahun 2002 Tentang Perlindungan Anak, pasal 1 menyebutkan, "Anak adalah seseorang yang belum berusia 18 (delapan belas) tahun, termasuk anak yang masih dalam kandungan". Demikian juga dengan Undang-Undang No.21 Tahun 2007 Tentang Pemberantasan Tindak Pidana Perdagangan Orang, dalam Ketentuan Umum, ayat 5 menyebutkan," Anak adalah seseorang yang belum berusia 18 (delapan belas) tahun, termasuk anak yang masih dalam kandungan."

Dari gambaran definisi tersebut, tampak sudah ada kesesuaian definisi anak dalam instrumen terkait dengan perdagangan anak, yaitu antara instrumen internasional dengan undang-undang di Indonesia. Konsekuensinya semua warga negara Indonesia yang masih dalam batasan umur di atas, berhak memperoleh standar perlindungan sesuai Konvensi Hak Anak. Selanjutnya, bagaimanakah kebijakan dan undang-undang yang ada mengatur tentang definisi perdagangan anak. Dalam Concluding Observations, tahun 2004 salah satu Rekomendasi Komite No.2 adalah: Menetapkan definisi yang tepat dari perdagangan manusia, meningkatkan perlindungan hukum untuk anak-anak yang menjadi korban, mengambil tindakan-tindakan efektif untuk mempertegas penegakan hukum, dan meningkatkan intensitas daya upaya untuk menggalang kesadaran masyarakat tentang penjualan, perdagangan dan penculikan anak-anak;

Dari rekomendasi tersebut, komite menekankan Indonesia harus menetapkan definisi yang tepat dari perdagangan anak. Dalam penentuan definisi perdagangan orang, dokumen internasional yang bisa digunakan sebagai rujukan adalah The UN

${ }^{17}$ Distia Aviandar, dkk, Analisis Situasi Hak Anak untuk Isu-isu Tertentu, h. 57. 
Protocol to Prevent, Suppress and Punish Perdagangan in Persons, Especially Women and Children, Supplementing the UN Convention against Transnational Orgzanized Crime atau Protokol Palermo. Protokol ini merupakan pelengkap dari konvensi induk "United Convention against Transnational Organized Crimes". Walaupun pemerintah Indonesia belum meratifikasi konvensi ini, tetapi Indonesia sudah menandatanganinya, sehingga sudah terikat secara moral untuk melaksanakannya. ${ }^{18}$

Berdasarkan protokol palermo, definisi perdagangan anak adalah:

a. "Rekrutmen, pengangkutan, pemindahtanganan, penampungan atau penerimaan orang, dengan ancaman atau penggunaan kekuatan atau bentukbentuk pemaksaan lainnya, dengan penculikan, muslihat, atau tipu daya, dengan penyalahgunaan kekuasaan atau penyalahgunaan posisi rawan atau dengan pemberian atau penerimaan pembayaran atau keuntungan guna memperoleh persetujuan sadar (consent) dari orang yang memegang kontrol atas orang lainnya, untuk tujuan eksploitasi. Eksploitasi meliputi, setidaktidaknya, eksploitasi prostitusi orang lain atau bentuk-bentuk eksploitasi seksual lainnya, kerja atau layanan paksa, perbudakan atau praktek-praktek serupa perbudakan, perhambaan atau pengambilan organ tubuh" [Protokol Palermo, Pasal 3(a)];

b. "Rekrutmen, pengangkutan, pemindah-tanganan, penampungan atau penerimaan anak untuk tujuan eksploitasi harus dianggap "perdagangan orang" walaupun tidak melibatkan cara-cara seperti yang ditetapkan dalam sub paragraf (a) dari pasal ini" [Protokol Palermo, Pasal 3(c)];

c. Anak" berarti setiap orang yang berumur kurang dari delapan belas 1 tahun [Protokol Palermo, Pasal 3(d)]. ${ }^{19}$

Protokol Palermo menjelaskan unsur cara dalam proses terjadinya perdagangan anak, adalah tidak relevan. Jadi tanpa adanya ancaman atau penggunaan kekuatan atau bentuk-bentuk pemaksaan lainnya, dengan penculikan, muslihat, atau tipu daya, dengan penyalahgunaan kekuasaan atau penyalahgunaan posisi rawan atau dengan pemberian atau penerimaan pembayaran atau keuntungan guna memperoleh persetujuan sadar (consent) dari orang yang memegang kontrol atas orang lainnya, maka tetap dianggap sebagai kasus perdagangan anak. ${ }^{20}$

Sedangkan definisi perdagangan manusia di Indoenasia berdasarkan UndangUndang No.21 Tahun 2007 Tentang Pemberantasan Tindak Pidana Perdagangan Orang (PTPPO), pasal 1 yang berbunyi:

"Perdagangan orang adalah tindakan perekrutan, pengangkutan, penampungan, pengiriman, pemindahan, atau penerimaan seseorang dengan ancaman kekerasan, penggunaan kekerasan, penculikan, penyekapan, pemalsuan, penipuan, penyalahgunaan kekuasaan atau posisi rentan, penjeratan utang atau memberi bayaran atau manfaat, sehingga memperoleh persetujuan dari orang yang memegang kendali atas orang lain tersebut, baik yang dilakukan di dalam

\footnotetext{
${ }^{18}$ Distia Aviandar, dkk, Analisis Situasi Hak Anak untuk Isu-isu Tertentu, h. 58.

${ }^{19}$ Distia Aviandar, dkk, Analisis Situasi Hak Anak untuk Isu-isu Tertentu, h. 59.

${ }^{20}$ Distia Aviandar, dkk, Analisis Situasi Hak Anak untuk Isu-isu Tertentu, h. 59.
} 
negara maupun antar negara, untuk tujuan eksploitasi atau mengakibatkan orang tereksploitasi”.

Dalam Undang-Undang No. 21 Tahun 2007 Tentang Pemberantasan Tindak Pidana Perdagangan Orang ini tidak ada penjelasan lainnya sehingga pengertian perdagangan orang dalam undang-undang ini untuk semua orang tanpa ada perbedaan batasan umur. Artinya ada ketidaksesuaian antara Undang-Undang No.21 Tahun 2007 Tentang Pemberantasan Tindak Pidana Perdagangan Orang dengan Protokol Palermo. Protokol Palermo menyatakan jika korbannya masih anak-anak maka tidak adanya unsur cara dalam proses terjadinya perdagangan anak, tetaplah di anggap kasus perdagangan anak. Sedangkan dalam Undang-Undang No.21 Tahun 2007 Tentang Pemberantasan Tindak Pidana Perdagangan Orang tidak mengatur itu. ${ }^{21}$

Menurut Undang-Undang No. 14 Tahun 2009 (Undang-Undang mengenai ratifikasi Protokol untuk Mencegah dan Menghukum Perdagangan Manusia, terutama Perempuan dan Anak, atau yang dikenal dengan Protokol Palermo) memberikan penjelasan mengenai perdagangan anak, yaitu; perekrutan, transportasi, transfer, penyembunyian atau penerimaan seseorang anak untuk maksud eksploitasi harus dianggap "memperdagangkan manusia" bahkan bila hal ini tidak melibatkan semua cara kekerasan atau bentuk pemaksaan lainnya, penculikan, pemalsuan, penipuan, penyalahgunaan kekuasaan atau penyalahgunaan posisi rentan atau memberikan atau menerima pembayaran, atau keuntungan untuk mendapat izin dari orang yang memegang kendali atas orang lain. ${ }^{22}$

Anak yang diperdagangkan setidaknya mengalami beberapa proses:

a. Direkrut, yaitu pada proses ini anak direkrut dari desa atau daerah asalnya dengan cara bujuk rayu, pemaksaan, penculikan, penyekapan, baik oleh orang yang dikenal maupun tidak dikenal.

b. Dipindahkan, yaitu pemindahan ini dilakukan dari satu tempat ke tempat yang lain baik masih berada di dalam negeri maupun di luar negeri. Pemindahan ini dilakukan dengan menggunakan berbagai angkutan, baik darat, laut maupun udara. Pada proses ini, anak dipindahkan ke daerah yang tidak dikenal anak sebelumnya, sehingga anak tidak bisa kembali atau mengetahui jalan pulang ke daerah asalnya.

c. Ditampung, yaitu Proses pemindahan seringkali melibatkan banyak tempat. Sebelum anak diserah terimakan kadangkala anak-anak ditampung dulu, baik di rumah pelaku, maupun di tempat lainnya, seperti hotel, tempat penampungan lain, atau di satu komunitas. Di tempat ini anak diawasi gerak-geriknya sehingga sulit untuk melarikan diri. Pada proses ini anak sudah mendapatkan perlakuan eksploitasi.

d. Dipindahtangankan atau diserahkan dari seseorang ke orang lain. Pemindahtangan ini biasanya dilakukan ketika anak sudah berada di daerah tujuan. Anak diserahkan oleh pelaku yang membawa anak dari daerah asal

\footnotetext{
${ }^{21}$ Distia Aviandar, dkk, Analisis Situasi Hak Anak untuk Isu-isu Tertentu, h. 60.

${ }^{22}$ Nurhamidah, Buku Saku Pencegahan Perdagangan Anak: Lindungi Kami dari Jerat Perdagangan Anak (Jakarta: Yayasan KKSP- Pusat Pendidikan dan Informasi Hak Anak, 2014), h. 7.
} 
kepada pelaku yang berada di daerah tujuan untuk dipekerjakan dan dieksplitasi. ${ }^{23}$

Adapun dalam protokol PBB, yang dimaksud dengan perdagangan perempuan dan anak adalah: ${ }^{24}$

a. Perekrutan, pengiriman, pemindahan, penampungan atau penerimaan seseorang, dengan ancaman atau penggunaan kekerasan atau bentuk-bentuk lain dari pemaksaan, penculikan, penipuan, kebohongan atau penyalahgunaan kekuasaan atau posisi rentan atau memberi atau menerima pembayaran atau memperoleh keuntungan agar dapat memperoleh persetujuan dari seseorang yang berkuasa atas orang lain, untuk tujuan eksploitasi. Eksploitasi termasuk, paling tidak, eksploitasi untuk melacurkan orang lain atau bentuk-bentuk lain dari eksploitasi seksual, kerja atau pelayanan paksa, perbudakan atau praktik-praktik serupa perbudakan, penghambaan atau pengambilan organ tubuh.

b. Persetujuan korban perdagangan orang terhadap eksploitasi.

c. Perekrutan, pengiriman, pemindahan, penampungan atau penerimaan seorang anak atau untuk tujuan eksploitasi dipandang sebagai perdagangan orang bahkan jika kegiatan ini tidak melibatkan satu pun cara yang dikemukakan dalam sublinea (a) pasal ini.

d. Anak adalah setiap orang yang berumur di bawah 18 tahun.

lain:

Ada beberapa bentuk tindak pidana perdagangan anak (child trafficking) antara

a. Anak yang dikerjakan dalam bisnis pelacuran dan pornografi

Dewasa ini, industri seks telah menjelma dalam berbagai bentuk. Jasa pelayanan seks terjadi tidak hanya di tempat lokalisai, tetapi diluar lokalisasi juga semakin marak. Tempat-tempat yang biasanya secara sembunyi digunakan sebagai tempat pelayanan seks di antaranya perumahan, hotel bar, restoran, diskotik, salon kecantikan, dan cafe. Tempat-tempat tersebut menyediakan teman pendamping atau teman kencan.

b. Anak yang dijadikan pengemis

Pola lain perdagangan anak yang sering dijumpai di berbagai daerah di Indonesia adlaah mengambil anak untuk mengemis di jalanan. Anak-anak yang disuruh mengemis di jalan-jalan di kota-kota besar sering kali berasal dari tempat yang jauh. Jumlah anak yang direkrut dari daerah perdesaan yang cukup besar, anak-anak tersebut dijanjikan pekerjaan yang layak di kota, tetapi mereka tidak tahu sesampainya di kota, mereka disuruh mengemis. Selain anak yang diperdagangkan untuk dijadikan pengemis wanita sepaya kelihatan memelas.

c. Anak yang dijadikan pembantu rumah tangga

\footnotetext{
${ }^{23}$ Nurhamidah, Buku Saku Pencegahan Perdagangan Anak: Lindungi Kami dari Jerat Perdagangan Anak, h. 9.

${ }^{24}$ Ruth Rosenberg, Perdagangan Perempuan dan Anak di Indonesia (Jakarta: USAID, 2003), h. $14-15$.
} 
Anak yang dijadikan pembantu rumah tangga merupakan pekerjaan termudah yang dapat dilakukan anak perempuan desa yang tidak berpengalaman dan tidak atau kurang berpendidikan dan yang orang tuanya tidak mempunyai cukup biaya untuk menyekolahkan atau melanjutkan sekolah anaknya. Seringkali, kota besar menjadi obsesi banyak kaum muda di pedesaan mereka tergiur oleh gaya hidup kota yang dilihatnya melalui media cetak dan televisi.

d. Anak yang dimanfaatkan dalam perdagangan narkoba

Anak-anak yang dipekerjakan sebagai pengedar atau pengunaan narkoba sifatnya sangat terorganisir. Mereka dipekerjakan sebagai pembantu dalam sindikat narkoba dengan iming-iming akan diberikan gaji yang cukup besar.

e. Anak yang mengerjakan pekerjaan lain yang sifatnya sangat eksploitatif, seperti pekerjaan dijermal, yaitu anak dipekerjakan para perusahaan tertentu yang mana anak tersebut diberikan gaji yang murah. ${ }^{25}$

Ada empat hal sifat dasar trafficking, yaitu pertama, bersifat manipulatif atau penyalahgunaan, yaitu penyimpangan dari rencana semula atau hal yang diinformasikan kepada korban. Pada saat membujuk dikatakan akan diberikan pekerjaan layak tetapi pada kenyataannya dijadikan budak, dieksploitasi, dipekerjakan pada pekerjaan buruk, dijadikan obyek transpalantasi, dan sebagainya. Kedua, ada transaksi dalam trafficking terjadi transaksi uang antara calo, penjual dan pembeli atau pemakai. Ketiga, tidak mengerti, yakni korban pada umumnya tidak mengerti bahwa ia akan menjadi korban tindak pidana, karena ketika akan bermigrasi dalam niatnya akan mencari pekerjaan atau tujuan lainnya yang tidak ada hubunga dengan sindikat tindak pidana. Keempat, ada migrasi, yaitu perpindahan korban yang melampaui batas negara atau pbatas propinsi. Karena faktor jarak dan melampaui batas-batas administrasi, maka trafficking biasanya dilakukan oleh sebuah sindikat. ${ }^{26}$

Trafficking, khususnya perdagangan anak harus dilawan karena merupakan tindakan yang bertentangan dengan harkat dan martabat manusia dan melanggar hak asasi manusia. Kenyataan menunjukkan bahwa trafficking telah meluas dalam bentuk jaringan kejahatan yang terorganisisr dan tidak terorganisir, baik bersifat antarnegara maupun dalam negeri, sehingga menjadi ancaman terhadap norma-norma kehidupan yang dilandasai penghormatan terhadap hak asasi manusia. Keinginan untuk menyelamatkan anak dari ancaman trafficking didasari pada nilai-nilai luhur, komitmen nasional dan internasional, untuk melakukan upaya pencegahan sejak dini, penindakan terhadap pelaku, perlindungan korban, dan peningkatan kerja sama.

Perdagangan anak bukan sebuah bentuk pekerjaan, namun suatu proses pengerahan atau pengangkutan dan penerimaan seorang anak atau orang dewasa untuk keperluan eksploitasi, dimana selama dalam proses itu hak-hak asasi manusia dilanggar. Faktor utama dalam semua bentuk pekerjaan yang mutlak dilarang (perbudakan atau yang mirip dengan perbudakan, penjualan dan perdagangan anak, ijon, penghambaan, dan kerja paksa dan wajib kerja) adalah bahwa orang tidak bebas

\footnotetext{
${ }^{25}$ Marlina dan Azmiati Zuliah, Hak Restitusi terhadap Koran Tindak Pidana Perdagangan Orang (Bandung: Refika Aditama, 2015), h. 7-8.

${ }^{26}$ Beniharmoni Harefa, Kapita Selekta Perlindungan Hukum Bagi Anak (Ed. I; Cet. I; Yogyakarta: Deepublish, 2016), h. 76.
} 
meninggalkan pekerjaannya atau merundingkan kondisi-kondisi lainnya. Perdebatan tentang definisi perdagangan diselesaikan pada tahun 2000 dengan hukum internasional yang menjelaskan bahwa anak (manusia yang berusia kurang dari 18 tahun) harus dianggap sebagai diperdagangkan, bahkan bila mereka lebih diijinkan untuk berimigrasi untuk memperoleh pekerjaan. ${ }^{27}$

\section{b. Sistem Sanksi Perdagangan Anak di Indonesia}

Mengingat korban dalam tindak pidana perdagangan orang ini biasa laki-laki atau perempuan, dewasa ataupun anak-anak, maka Undang-Undang No. 21 Tahun 2007 tentang Pemberantasan Tindak Pidana Perdagangan Orang hanya menyebutkan orang dan tidak secara khusus menyebut anak. Meski demikian, dalam Bab I tentang Ketentuan Umum pada Pasal 1 ayat di sebutkan bahwa yang dimaksud dengan:

"Anak adalah seseorang yang belum berusia 18 (delapan belas) tahun, termasuk anak yang masih dalam kandungan". ${ }^{28}$

Menurut ketentuan Pasal 2 ayat 1 Undang-Undang No. 21 Tahun 2007 tentang Pemberantasan Tindak Pidana Perdagangan Orang bahwa:

"Setiap orang yang melakukan perekrutan, pengangkutan, penampungan, pengiriman, pemindahan, atau penerimaan seseorang dengan ancaman kekerasan, penggunaan kekerasan, penculikan, penyekapan, pemalsuan, penipuan, penyalahgunaan kekuasaan atau posisi rentan, penjeratan utang, atau memberi bayaran atau manfaat walaupun memperoleh persetuujuan dari orang yang memegang kendali atas orang lain, untuk tujuan mengeksploitasi orang tersebut di wilayah negara Republik Indonesia, dipidana dengan pidana penjara paling singkat 3 (tiga) tahun dan paling lama 15 (lima belas) tahun dan pidana denda paling sedikit Rp. 120.000.000,-(Seratus dua puluh juta rupiah) dan paling banyak Rp. 600.000.000,-(Enam ratus juta rupiah)". ${ }^{29}$

Setiap orang yang memasukkan orang lain ke wilayah Indonesia dengan tujuan untuk mengeksploitasi juga digolongkan sebagai tindak pidana perdagangan orang. Pasal 3 Undang-Undang No. 21 Tahun 2007 tentang Pemberantasan Tindak Pidana Perdagangan Orang, yang menyatakan bahwa:

"Setiap orang yang memasukan orang ke wilayah negara Republik Indonesia dengan maksud untuk dieksploitasi di wilayah negara Republik Indonesia atau dieksploitasi di negara lain dipidana dengan pidana penjara paling singkat 3 (tiga) tahun dan paling lama 15 (lima belas) tahun dan pidana denda paling

\footnotetext{
${ }^{27}$ Beniharmoni Harefa, Kapita Selekta Perlindungan Hukum Bagi Anak, h. 77.
}

${ }^{28}$ Republik Indonesia, Pasal 1 Ayat 7 Undang-Undang No. 21 Tahun 2007 tentang Pemberantasan Tindak Pidana Perdagangan Orang, Dikutip dalam buku Marlina dan Azmiati Zuliah, Hak Restitusi terhadap Korban Tindak Pidana Perdagangan Orang (Bandung: Refika Aditama, 2015), h. 141.

${ }^{29}$ Republik Indonesia, Pasal 2 Ayat 1 Undang-Undang No. 21 Tahun 2007 tentang Pemberantasan Tindak Pidana Perdagangan Orang, Dikutip dalam buku Marlina dan Azmiati Zuliah, Hak Restitusi terhadap Korban Tindak Pidana Perdagangan Orang, h. 142. 
sedikit Rp. 120.000.000,- (seratus dua puluh juta rupiah) dan paling banyak Rp. 600.000.000,- (Enam ratus juta rupiah)". 30

Begitu pula sebaliknya, jika setiap orang membawa warga Indonesia ke luar wilayah Indonesia dengan tujuan untuk dieksploitasi, dapat dikenai ketentuan Pasal 4 Undang-Undang No. 21 Tahun 2007 tentang Pemberantasan Tindak Pidana Perdagangan Orang, yang menentukan bahwa:

"Setiap orang yang membawa warga negara Indonesia ke luar wilayah negara Republik Indonesia dengan maksud untuk dieksploitasi di luar wilayah negara Republik Indonesia dipidana dengan pidana penjara paling singkat 3 (tiga) tahun dan paling lama 15 (lima belas) tahun dan pidana denda paling sedikit Rp. 120.000.000,- (Seratus dua puluh juta rupiah) dan paling banyak Rp. $600.000 .000,-$ (Enam ratus juta rupiah)".

Jika tindak pidana dilakukan terhadap anak, sebagaimana dimaksud dalam Pasal 2, 3, dan 4 dilakukan terhadap anak, ancaman pidana ditambah 1/3. Terdapat pada Pasal 17 Undang-Undang No. 21 Tahun 2007 tentang Pemberantasan Tindak Pidana Perdagangan Orang, yang menentukan bahwa:

"Jika tindak pidana sebagaimana dimaksud dalam Pasal 2, Pasal 3, dan Pasal 4 dilakukan terhadap anak, maka ancaman pidananya ditambah 1/3 (sepertiga)". 32

Tindak pidana perdagangan orang dengan berkedok pengangkatan anak juga sering terjadi. Karena itu, berdasarkan ketentuan Pasal 5 Undang-Undang No. 21 Tahun 2007 tentang Pemberantasan Tindak Pidana Perdagangan Orang, pengangkatan anak yang bertujuan mengeksploitasi anak dapat dikenal hukum pidana penjara,

"Setiap orang yang melakukan pengangkatan anak dengan menjanjikan sesuatu atau memberikan sesuatu dengan maksud untuk dieksploitasi dipidana dengan pidana penjara paling singkat 3 (tiga) tahun dan paling lama 15 (lima belas) tahun dan pidana denda paling sedikit Rp. 120.000.000,- (seratus dua puluh juta rupiah) dan paling banyak Rp. 600.000.000,- (Enam ratus juta rupiah)". 33

Apabila seseorang anak mengirim anak, baik ke dalam wilayah Indonesia maupun ke luar wilayah Indonesia, dapat dikenai sanksi pidan dan denda jika pengiriman itu mengakibatkan anak tereksploitasi. Hal itu diatur dalam Pasal 6

${ }^{30}$ Republik Indonesia, Pasal 3 Undang-Undang No. 21 Tahun 2007 tentang Pemberantasan Tindak Pidana Perdagangan Orang, Dikutip dalam buku Marlina dan Azmiati Zuliah, Hak Restitusi terhadap Korban Tindak Pidana Perdagangan Orang, h. 142.

${ }^{31}$ Republik Indonesia, Pasal 4 Undang-Undang No. 21 Tahun 2007 tentang Pemberantasan Tindak Pidana Perdagangan Orang, Dikutip dalam buku Marlina dan Azmiati Zuliah, Hak Restitusi terhadap Korban Tindak Pidana Perdagangan Orang, h. 142.

${ }^{32}$ Republik Indonesia, Pasal 17 Undang-Undang No. 21 Tahun 2007 tentang Pemberantasan Tindak Pidana Perdagangan Orang, Dikutip dalam buku Marlina dan Azmiati Zuliah, Hak Restitusi terhadap Korban Tindak Pidana Perdagangan Orang, h. 147.

${ }^{33}$ Republik Indonesia, Pasal 5 Undang-Undang No. 21 Tahun 2007 tentang Pemberantasan Tindak Pidana Perdagangan Orang, Dikutip dalam buku Marlina dan Azmiati Zuliah, Hak Restitusi terhadap Korban Tindak Pidana Perdagangan Orang, h. 144. 
Undang-Undang No. 21 Tahun 2007 tentang Pemberantasan Tindak Pidana Perdagangan Orang, yang menentukan bahwa:

"Setiap orang yang melakukan pengiriman anak ke dalam atau ke luar negeri dengan cara apapun yang mengakibatkan nak tersebut tereksploitasi dipidana dengan pidana penjara paling singkat 3 (tiga) tahun dan paling lama 15 (lima belas) tahun dan pidana denda paling sedikit Rp. 120.000.000,-(Seratus dua puluh juta rupiah) dan paling banyak Rp. 600.000.000,-(Enam ratus juta rupiah)" 34

Sedangkan, dalam Undang-Undang No. 23 Tahun 2002 tentang Perlindungan Anak memberikan perlindungan khusus terhadap perdagangan anak, yaitu:

Pasal 78

"Setiap orang yang mengetahui dan sengaja membiarkan anak dalam situasi darurat sebagaimana dimaksud dalam Pasal 60, anak yang berhadapan dengan hukum, anak dari kelompok minoritas dan terisolasi, anak yang tereksploitasi secara ekonomi dan/atau seksual, anak yang diperdagangkan, anak yang menjadi korban penyalahgunaan narkotika, alkohol, psikotropika, dan zat adiktif lainnya (napza), anak korban penculikan, anak korban perdagangan, atau anak korban kekerasan sebagaimana dimaksud dalam Pasal 59, padahal anak tersebut memerlukan pertolongan dan harus dibantu, dipidana dengan pidana penjara paling lama 5 (lima) tahun dan/atau denda paling banyak Rp 100.000.000,00 (seratus juta rupiah)". 35

Pasal 83

"Setiap orang yang memperdagangkan, menjual, atau menculik anak untuk diri sendiri atau untuk dijual, dipidana dengan pidana penjara paling lama 15 (lima belas) tahun dan paling singkat 3 (tiga) tahun dan denda paling banyak Rp 300.000.000,00 (tiga ratus juta rupiah) dan paling sedikit Rp 60.000.000,00 (enam puluh juta rupiah)". ${ }^{36}$

\section{METODOLOGI PENELITIAN}

Jenis penelitian ini merupakan penelitian studi pustaka (library research). Peneliti menggunakan pendekatan teologis (syar'i) dan pendekatan yuridis normatif. Sumber data penelitian meliputi dokumen-dokumen resmi, hasil-hasil penelitian, dan sebagainya yang merupakan produk hukum dan dapat diklasifikasikan pada dua dua bagian yakni: a) bahan Hukum Primer, yaitu bahan-bahan hukum yang mengikat dan terdiri dari: Al-Qur'an, Hadis, Undang-Undang Dasar 1945, Kitab Undang-Undang Hukum Pidana (KUHP), Undang-Undang No. 23 Tahun 2002 tentang Perlindungan

\footnotetext{
${ }^{34}$ Republik Indonesia, Pasal 6 Undang-Undang No. 21 Tahun 2007 tentang Pemberantasan Tindak Pidana Perdagangan Orang, Dikutip dalam buku Marlina dan Azmiati Zuliah, Hak Restitusi terhadap Korban Tindak Pidana Perdagangan Orang, h. 144.

${ }^{35}$ Republik Indonesia, Pasal 78 Undang-Undang No. 23 Tahun 2002 tentang Perlindungan Anak, Dikutip dalam buku Rika Saraswati, Hukum Perlindungan Anak di Indonesia (Bandung: Citra Aditya Bakti, 2015), h. 198.

${ }^{36}$ Republik Indonesia, Pasal 83 Undang-Undang No. 23 Tahun 2002 tentang Perlindungan Anak, Dikutip dalam buku Rika Saraswati, Hukum Perlindungan Anak di Indonesia, h. 200.
} 
Anak, Undang-Undang Republik Indonesia No. 35 Tahun 2014 Tentang Perubahan Atas Undang-Undang No. 23 Tahun 2002 Tentang Perlindungan Anak, UndangUndang No. 21 Tahun 2007 tentang Pemberantasan Tindak Pidana Perdagangan Orang, Keputusan Presiden Republik Indonesia Nomor 88 Tahun 2002 tentang Rencana Aksi Nasional Penghapusan Perdagangan (Trafficking) Perempuan dan Anak, Keputusan Presiden Nomor 36 Tahun 1990 tentang Pengesahan Convention on the Rights of The Child (Konvensi tentang Hak-hak Anak); b) Bahan Hukum Sekunder, yaitu bahan yang akan memberikan penjelasan tentang bahan hukum primer, terdiri dari: Berbagai tulisan pakar hukum pidana dan kriminologi yang berkaitan dengan perdagangan anak, yang dituangkan dalam bentuk buku, paper atau makalah serta tulisan-tulisan ilmiah lainnya, dan berbagai hasil penelitian yang pernah dilakukan berkaitan dengan perdagangan anak, baik dari perspektif hukum, maupun non-hukum; c) Bahan Hukum Tertier, yaitu bahan yang memberikan petunjuk maupun penjelasan lebih lanjut mengenai bahan hukum primer dan bahan hukum sekunder, yang terdiri dari: Kamus Besar Bahasa Indonesia, Kamus Ilmiah, dan Kamus Hukum. Dalam menganalisis data penelitian pustaka tersebut, peneliti memperdalam pengetahuan tentang masalah yang akan diteliti sehingga dapat melakukan kontrol penelitian. Menegaskan kerangka teoritis yang menjadi landasan jalan pemikiran peneliti.

\section{HASIL PENELITIAN DAN PEMBAHASAN}

Dalam literatur klasik Islam, istilah trafficking atau perdagangan orang menurut pandangan ulama bisa jadi tidak pernah disebut, karana trafficking merupakan fenomena baru perbudakan modern. Karena itu definisi trafficking tidak ditemukan dalam literatur filh Islam klasik.

Praktik trafficking secara terang benderang adalah tindak kejahatan kemanusiaan yang pasti bertolak belakang dengan ajaran Islam. Fiqh anti trafficking merupakan sebuah pemahaman keagamaan yang didasarkan pada semangat kemanusiaan yang ditegaskan ayat-ayat al-Qur'an dan teks-teks Hadits untuk menumbuhkan kesadaran kolektif tentang bahaya dan keharaman tindak kejahatan dan perlunya perlindungan korban. ${ }^{37}$

Perdagangan orang dalam sejarah Islam sebenarnya terjadi semenjak adanya perbudakan. Perbudakan terjadi pada umat terdahulu jauh sebelum Nabi Muhammad saw diut us. Diantara salah satu sebab suburnya perbudakan waktu itu adalah seringnya terjadi peperangan antar kabilah dan bangsa, di samping itu terdapat juga faktor lain seperti perampokan, perampasan, penculikan, kemiskinan, ketidakmampuan dalam membayar utang dan lain sebagainya, serta didukung pula dengan adanya pasar budak pada masa itu. ${ }^{38}$

Perbudakan manusia terhadap manusia telah berjalan berabad-abad lamanya. Tetapi, para ahli sejarah tidak dapat menentukan kapan permulaan perbudakan itu dimulai. Sebagian ahli sejarah, berpendapat bahwa perbudakan itu dimulai bersamaan dengan perkembangan manusia, karena sebagian manusia memerlukan bantuan tenaga

\footnotetext{
${ }^{37}$ Faqihuddin Abdul Kodir, dkk, Fiqh Anti Trafficking: Jawaban atas Berbagai Kasus Kejahatan Perdagangan Manusia dalam Perspektif Hukum Islam (Bandung: Fahmina Institute, 2006), h. 12-.

${ }^{38}$ Nurhayati, Perbudakan Zaman Modern: Perdagangan Orang dalam Perspektif Ulama, (Medan: Perdana Publishing. 2016), h. 109.
} 
dari sebagaian manusia lainnya. Karena sebagian manusia merasa mempunyai kekuatan, maka lahirlah keinginan menguasai orang lain. Setiap orang yang mempunyai budak akan dianggap mempunyai status sosial yang tinggi, sehingga hal ini merupakan suatu hal yang umum terjadi. ${ }^{39}$

Pada zaman Nabi Ibrahim as perbudakan sudah terjadi. Hal ini ditunjukkan oleh kisah Sarah yang memberikan jariyah (budak wanita) yang dimilikinya yang bernama Hajar kepada Nabi Ibrahim as untuk dinikahi. Karena setelah beberapa tahun pernikahan Ibrahim dan Sarah tak kunjung dikarunia anak. Apalagi kini, usianya beranjak semakin tua. Ia berharap Hajar dapat memberikan seorang anak kepada mereka yang akan menerangi rumah itu dengan keceriaan dan kebahagiaan. Keinginan Sarah terwujud, Hajar mengandung dan akhirnya melahirkan seorang anak laki-laki yang bernama Ismail. ${ }^{40}$

Praktik-praktik perdagangan orang juga terdapat pada zaman sebelum Islam atau disebut dengan zaman jahilliyah (era kebodohan). Pada zaman ini banyak orang yang tidak memahami bahwa manusia adalah ciptaan Allah swt, yang merdeka (bebas), serta otonom, dan harus dihormati. Kelompok-kelompok yang paling rentan sebagai sasaran penindasan dan penghinaan adalah perempuan, anak-anak dan orang-rang yang miskin. Penindasan oleh yang kaya dan kuat banyak terjadi terhadap yang miskin dan lemah dan perbuatan ini tidak dianggap sebagai pelanggaran. ${ }^{41}$

Perempuan adalah kelompok yang paling banyak menjadi korban. Kelahiran bayi perempuan dianggap membuat aib keluarga dan akan mendatangkan sial bagi keluarga. Bayi perempuan yang lahir akan disembunyikan oleh keluarganya, karena setiap bayi yang berjenis kelamin perempuan akan dibunuh dan dikubur hidup-hidup, selain itu kaum perempuan tidak berhak atas warisan, bahkan perempuan termasuk harta yang dapat diwariskan. Keadaan ini sangat merendahkan martabat dan derajat kaum perempuan, dan merendahkan sendi-sendi keluarga. ${ }^{42}$

Namun sejak Nabi Muhammad saw berupaya secara bertahap tetapi tegas memperbaiki dan merehabilitasi kedudukan para hamba tersebut, termasuk membuka berbagai solusi agar mereka mendapat perlakuan yang lebih baik. Barulah kemudian, para ulama kontemporer menyatakan dengan tegas bahwa Islam sangat mengutuk praktik perbudakan manusia, karena perbudakan bukan hanya pertentangan dengan prinsip kemanusia, melainkan juga bertentangan dengan doktin ajaran agama. Tak ada satu agamapun yang membenarkan tindakan yang merendahkan derajat kemanusiaan. ${ }^{43}$

Human trafficking adalah bentuk perbudakan modern yang harus diperangi bersama. Dengan memepertimbangkan nilai-nilai, perbudakan modern ini sudah

\footnotetext{
${ }^{39}$ Henny Nuraeny, Tindak Pidana Perdagangan Orang: Kebijakan Hukum Pidana dan Pencegahannya (Jakarta: Sinar Grafika, 2011), h. 90.

${ }^{40}$ Muhammad Ahmad Jadul Mawia, dkk, Qashash al-Qur'an, terj. Abdurrahman Assegaf, Kisahkisah Al-Qur'an (Jakarta: Zaman, 2009), h. 108-109.

${ }^{41}$ Nurhayati, Perbudakan Zaman Modern: Perdagangan Orang dalam Perspektif Ulama, h. 110111.

${ }^{42}$ Henny Nuraeny, Tindak Pidana Perdagangan Orang: Kebijakan Hukum Pidana dan Pencegahannya, h. 92.

${ }^{43}$ Nurhayati, Perbudakan Zaman Modern: Perdagangan Orang dalam Perspektif Ulama, h. 6.
} 
semestinya dihapuskan dari muka bumi. Karena human trafficking disebut sebagai perbudakan modern, menggali nilai Islam dari rekam jejak Nabi Muhammad saw dalam memerangi perbudakan adalah satu langkah strategis. Begitu juga upaya Nabi Muhammad saw dalam memeranginya pada masa awal Islam.

Upaya Nabi Muhammad saw dalam melawan perbudakan paling tidak ada empat langkah: pertama, mengangkat derajat budak setara dengan manusia normal yang lain serta bersikap baik kepadanya; kedua, memotivasi para Sahabat untuk berlomba dalam memerdekakan budak; ketiga, mengancam orang yang melakukan praktik human trafficking, dan keempat, menjadikan pembebasan budak sebagai mekanisme penerapan sanksi atas pelanggaran ajaran agama (kaffärah). ${ }^{44}$

Sebagaimana diketahui ketika Islam datang, perbudakan merupakan lembaga yang telah membudaya, tidak saja di kawasan Arabia, tetapi juga merata di bagianbagian dunia yang lain. Islam mengimbau kepada para pemilik budak untuk bersikap manusiawi terhadap budak-budak mereka, serta menjanjikan pahala yang besar kepada mereka yang memerdekakan budak mereka. Bahkan, hukum pidana Islam mengharuskan kepada pelaku tindakan pidana tertentu untuk memerdekakan budak sebagai bagian dari pembayaran denda. Banyak di anatara budaka yang telah dimerdekakan itu menjadi sahabat-sahabat dekat Nabi Muhammad saw. Salman alFarisi dan Bilal bin Rabah, yang dikenal sebagai mu'adzdzin al-Rasul ada dua dari mereka.

Dari ulasan tersebut dapat diketahui bahwa sejarah perdagangan orang dalam Islam berawal dari perbudakan. Perbudakan telah terjadi dari bangsa-bangsa terdahulu jauh sebelum Islam datang. Dapat dikatakan tak ada bangsa yang bebas dari perbudakan, perempuan dan anak-anak adalah kelompok yang paling banyak menjadi korban. Islam datang dengan gerakan pembebasan. Manusia dalam pandangan Islam adalah makhluk yang sangat dimuliakan Allah swt. Tak ada seorang pun yang boleh memperbudak manusia lainnya. ${ }^{45}$

Aktivitas dan pola trafficking yang terjadi misalnya korban tidak mendapatkan hak untuk beribadah dengan tenang, dan atau tidak mendapatkan hak perlindungan dan keselamatan jiwanya, dan atau tidak mendapatkan hak untuk mengemukakan pendapatnya secara bebas dan independen, dan atau tidak mendapatkan hak atas kehormatan organ reproduksinya, dan atau tidak mendapatkan hak-hak atas harta hasil pekerjaanya. Karena itu, trafficking bertentangan dengan ajaran Islam. Korban trafficking mengancam kehilangan 5 (lima) pokok tujuan risalah Islam yang menjadi hak-hak dasar manusia. Penghapusan trafficking pada dasarnya untuk mengembalikan hak-hak korban yang telah terampas. ${ }^{46}$

\footnotetext{
${ }^{44}$ Niki Alma Febriana Fauzi, Islam dan Human Trafficking: Upaya Nabi dalam Melawan Praktik Human Trafficking pada Masa Awal Islam. Muwazah, Jurnal Kajian Gender, Vol 9, No. 2 Desember 2017. Pusat Studi Gender dan Anak (PSGA) LP'2M, IAIN Pekalongan, h. 103.

${ }^{45}$ Nurhayati, Perbudakan Zaman Modern: Perdagangan Orang dalam Perspektif Ulama, h. 113114.

${ }^{46}$ Mufidah CH, Mengapa Mereka Diperdagangkan ?: Membongkar Kejahatan Trafficking dalam Perspektif Islam, Hukum dan Gender (Malang: UIN-Maliki Press, 2011), h. 66.
} 
Menurut al-Syatibi memberikan pendapatnya, dalam rangka mewujudkan kemaslahatan di dunia dan akhirat, ada lima unsur pokok yang harus dipelihara dan diwujudkan, yaitu:

1. Memelihara agama (hifz al-din),

2. Memelihara jiwa (hifz al-nafs),

3. Memelihara akal (hifz al-aqI),

4. Memelihara keturunan (hifz al-nash), dan

5. Memelihara harta (hifz al-mal). ${ }^{47}$

Menurut peneliti, tindak pidana perdagangan orang, terutama yang menjadi korban adalah anak-anak akan mengancam perkembangan pada anak-anak. Pada tujuan hukum Islam adalah memelihara agama (hifz al-din), memelihara jiwa (hifz al-nafs), memelihara akal (hifz al-aqI), memelihara keturunan (hifz al-nasI), dan memelihara harta (hifz al-mal), mengakibatkan anak akan kehilangan hak tidak mendapatkan hak untuk beribadah dengan tenang, tidak mendapatkan hak perlindungan dan keselamatan jiwanya, tidak mendapatkan hak untuk mengemukakan pendapatnya secara bebas dan independen, tidak mendapatkan hak atas kehormatan organ reproduksinya, dan tidak mendapatkan hak-hak atas harta hasil pekerjaanya.

Karena pada dasarnya anak dilahir untuk hidup, merdeka dan merasakan keamanan. Jaminan mengenai kemerdekaan dan kebebasan manusia dalam pengakuan Islam tentang martabat manusia, baik dalam pandangan Allah swt maupun dalam pandangan sesama makhluk. ${ }^{48}$ Pengakuan kemuliaan martabat manusia antara lain dijelaskan firman Allah swt dalam QS al-Isra'/17:70,

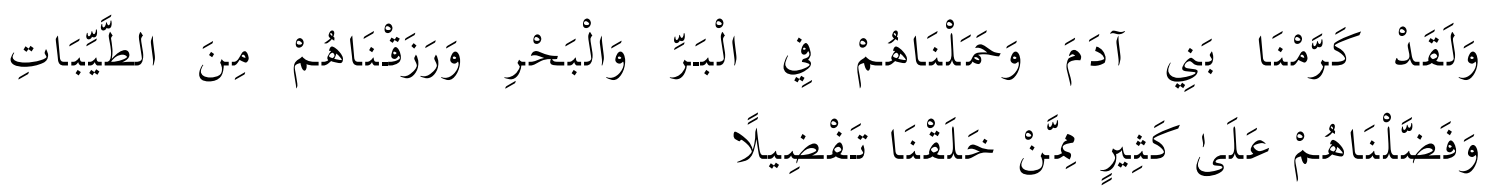

Terjemahnya:

Dan sungguh,kami telah memuliakan anak cucu Adam, dan kami angkut mereka di darat dan di laut, dan kami beri mereka rezki dari yang baik-baik dan kami lebihkan mereka di atas banyak makhluk yang kami ciptakan dengan kelebihan yang sempurna. ${ }^{49}$

Ayat ini menjelaskan sebab anugerah yakni karena manusia adalah makhluk unik yang memiliki kehormatan dalam kedudukannya sebagai manusia, baik taat beragama atau tidak. Dengan bersumpah sambil mengukuhkan pernyataanya dengan kata (قد) qad, ayat ini menyatakan bahwa dan Kami, yakni Allah swt bersumpah bahwa sesungguhnya telah kami muliakan anak cucu adam, dengan bentuk tubuh yang bagus, kemampuan berbicara dan berpikir, serta berpengetahuan dan Kami beri juga mereka,

\footnotetext{
${ }^{47}$ Muhammad Syukri Albani Nasution, Filsafat Hukum Islam, Ed. I; (Cet. II; Jakarta: Rajawali Press. 2014), h. 127.

${ }^{48}$ Topo Santoso, Membumikan Hukum Pidana Islam: Penegakan Syari'at dalam Wacana dan Agenda (Jakarta: Gema Insani Press, 2003), h. 71.

${ }^{49}$ Kementerian Agama Republik Indonesia, Al-Qur'an dan Terjemahnya, h. 394.
} 
atau yang Kami ilhami mereka pembuatannya, agar mereka dapat menjelajahi bumi dan angkasa yang kesemuanya Kami ciptakan untuk mereka dan kami juga beri mereka rezeki dari yang baik-baik, sesuai kebutuhan mereka, lagi lezat dan bermanfaat untuk pertumbuhan fisik dan perkembangan jiwa mereka dan kami lebihkan mereka atas banyak, makhluk dari siapa yang telah Kami ciptakan dengan kelebihan yang sempurna. Kami lebihkan mereka dari hewan, dengan akal, dan daya cipta, sehingga menjadi makhluk bertanggung jawab. Kami lebihkan yang taat dari mereka atas malaikat karena ketaatan malaikat tanpa tantangan. ${ }^{50}$

Kemudian dalam hadits tentang melindungi anak, yaitu:

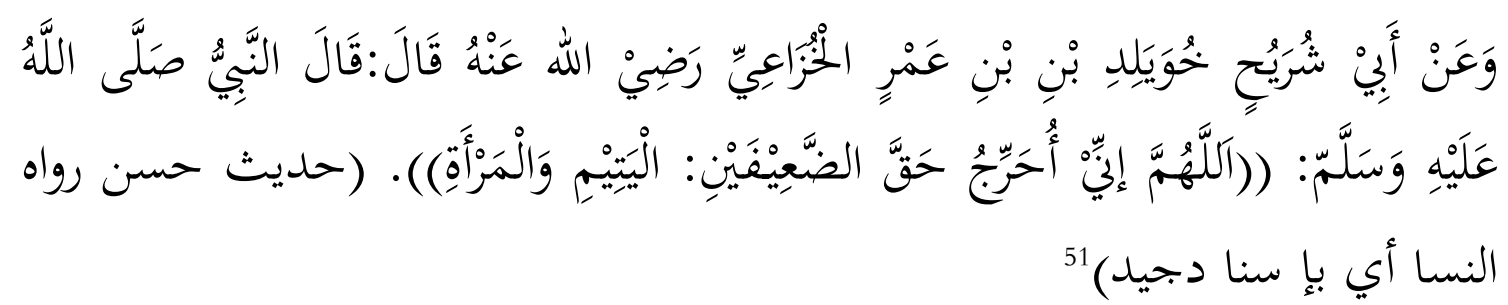

Artinya:

Dari Abu Syuraih Khuwailid bin Amr al-Khuza r.a, ia bercerita bahwasanya Nabi Muhammad saw pernah bersabda, "Ya Allah, sesungguhnya aku menganggap dosa orang yang menyiakan-nyiakan hak dua orang yang lemah: anak yatim dan wanita”.

Makna (أُحرِّجُ) ialah aku menganggap dosa, maksudnya berdosa bagi orang yang menyia-nyiakan hak kedua orang di atas, yakni anak yatim dan wanita, juga aku takut-takuti dengan sesangat-sangatnya orang yang melakukan sedemikian itu, bahkan aku benar-benar melarang, jangan sekali-kali dipermainkan hak-hak mereka itu.

Derajat hadits ini hasan. Hadits ini dinukilkan oleh Iman an-Nasai dalam alKurba (IX/495-Tuhfahul Asyraaf), Ibnu Majah (No. 3678), dan Ahmad (II/439) melalui jalur periwayatan Muhammad bin Ajlan dari Sa'id al-Maqburi darinya. Saya pun menilai sanadnya berderajat hasan, sebagaimana pendapat penulis (Imam an-Nawawi).

Kandungan haditsnya yaitu pentingnya berwasiat agar memperhatikan dan tidak menyia-nyiakan kaum yang lemah, yang tidak mampu melakukan apa-apa, yakni dari kalangan wanita dan anak yatim, dan tidak boleh menggangu mereka. Sungguh, mereka berlindung kepada Allah swt dengan kekuatannya, dan siapa saja yang berani menzhalimi mereka berhak mendapat dosa dan memperoleh siksa. ${ }^{52}$

Sejak lebih dari 1400 tahun yang lalu, hak tertentu telah mendapatkan jaminan berdasarkan Al-Qur'an, yang di antaranya adalah hak hidup, keamanan diri, kemerdekaan dan perlakuan yang sama. Di samping itu, Al-Qur'an juga

${ }^{50}$ M. Quraish Shihab, Tafsir Al-Misbah: Pesan, Kesan, dan Keserasian Al-Qur'an (Vol. VII; Jakarta: Lentera Hati, 2002), h. 521-522.

${ }^{51}$ Syaikh Salim bin 'Ied al-Hilali, Bahjatun Nazhirin Syarh Riyadhish Shalihin, terj. M. Abdul Ghoffar, Syarah Riyadhush Shalihin Jilid I (Jakarta: Pustaka Imam Syafi’i, 2012), h. 752.

${ }^{52}$ Syaikh Salim bin 'Ied al-Hilali, Bahjatun Nazhirin Syarh Riyadhish Shalihin, terj. M. Abdul Ghoffar, Syarah Riyadhush Shalihin Jilid I, h. 752-753. 
menekankan persamaan manusia. Karena salah satu unsur dasar sistem nilai Islam adalah prinsip keseimbangan atau persamaan. ${ }^{53}$

Hukum pidana Islam sebagai sebuah aturan yang diyakini oleh masyarakat Islam sebagai aturan yang diyakini oleh masyarakat Islam sebagai aturan yang bersumber dari Allah swt dan Rasulnya (al-Qur'an dan Sunnah) dan harus dilaksanakan secara konsekuen oleh masyarakat yang menganut ajaran Islam itu sendiri. ${ }^{54}$ Dalam hukum pidana Islam memiliki tujuan untuk mencegah kejahatan, yaitu:

1. Pencegahan dari aspek akidah atau iman, sebab dengan keimanan seseorang merasa terawasi oleh Allah swt, karena orang yang melakukan kejahatan apa saja di dunia disebabkan karena tidak memngingat Allah swt atau dengan kata lain imamnya tidak sedang, bersama dengannya,

2. Pencegahan dari aspek ibadah. Ibadah yang dilakukan dengan baik akan berdampak pada kebaikan perilaku,

3. Pencegahan dari segi keadilan sosial. Masyarakat pada Islam khususnya sudha diberi kesempatan untuk berusaha dan bekerja untuk memenuhu kebutuhannya dengan mencari pekerjaan yang halal lagi baik dan mencegah diri dari perbuatan yang tidak baik atau tidak halal,

4. Pencegahan dari segi amar makruf dan nahi mungkar. Tugas ini menjadi kewajiban semua masyarakat Islam untuk senantiasa beramal makruf dan mencegah diri dari perbuatan keji dan mungkar. Tujuan ini menjadi hal pokok dalam menegakkan syariat Islam. ${ }^{55}$

Adapun jika dihubungkan dengan tindak pidana perdagangan dengan hukum pidana Islam, maka dibagi menjadi beberapa jenis hukuman, yaitu:

\section{Jarimah hudud}

Jarimah hudud merupakan hukuman yang tidak bisa dihapuskan sebagi perbuatan melanggar hukuman yang jenis dan ancaman hukumannya ditentukan oleh nash, yaitu hukuman had (hak Allah swt) yang jumlahnya terbatas. ${ }^{56}$

Dalam hal, perdagangan orang khususnya yang menjadi objek kejahatan adalah anak-anak yaitu penculikan dengan cara kekerasan dan menampung dengan tujuan untuk mengeksploitasi anak-anak serta menjerumuskan anak-anak ke dalam dunia prostitusi. Perdagangan anak merupakan salah satu kejahatan yang membuat kerusakan dan membuat rasa tidak aman bagi orangtua terhadap anaknya. Dalam segi hukumannya, Allah swt berfirman dalam QS al-Maidah/5:33 yaitu,

\footnotetext{
${ }^{53}$ Topo Santoso, Membumikan Hukum Pidana Islam: Penegakan Syari'at dalam Wacana dan Agenda, h. 68.

${ }^{54}$ Hamzah Hasan, Kejahatan Kesusilaan Perspektif Hukum Pidana Islam (Makassar: Alauddin University Press, 2012), h. 12.

${ }^{55}$ Hamzah Hasan, Kejahatan Kesusilaan Perspektif Hukum Pidana Islam, h. 13.

${ }^{56}$ Mustofa Hasan, dan Beni Ahmad Saebani, Hukum Pidana Islam (Fiqh Jinayah): Dilengkap dengan Kajian Hukum Pidana Islam (Bandung: Pustaka Setia, 2013), h. 47.
} 


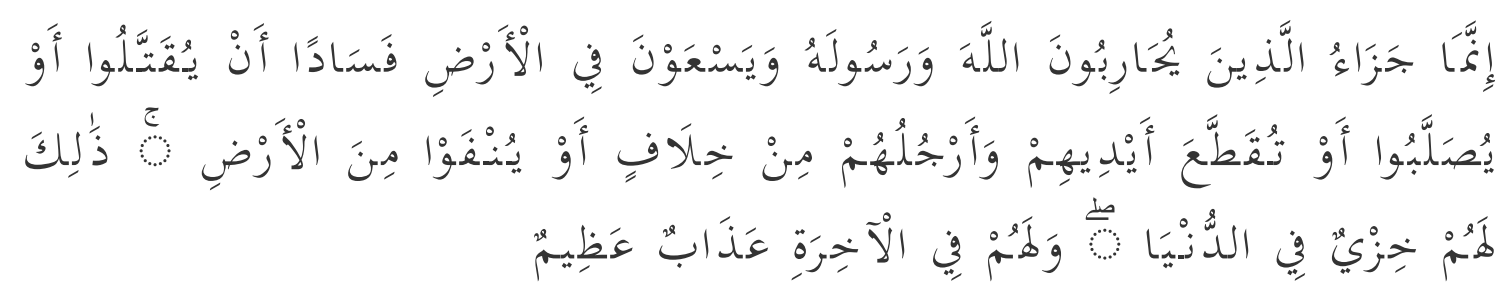

Terjemahnya:

"Hukuman bagi orang-orang yang memerangi Allah dan Rasul-Nya dan membuat kerusakan di muka bumi, hanyalah mereka dibunuh atau disalib, atau dipotong tangan dan kaki mereka secara silang, atau diasingkan dari tempat kediamannya. Yang demikian itu kehinaan untuk mereka didunia, dan di akhirat mereka mendapat azab yang besar". 57

\section{Jarimah Qisas/Diyat}

Jarimah Qisas adalah bentuk hukuman bagi pelaku jarimah terhadap jiwa dan anggota badan yang dilakukan dengan sengaja. Adapun diyat merupakan hukuman bagi pelaku jarimah dengan objek yang sama (nyawa dan anggota badan), tetapi dilakukan tanpa sengaja. ${ }^{58}$

Dalam hal, perdagangan anak sebagai salah satu kejahatan yang yang mengancam kelangsungan hidup sebagai manusia yang memiliki hak untuk hidup. Namun, dalam kasus trafficking, anak kadang menjadi korban pembunuhan, dimana organ tubuhnya dijual untuk diperjualbelikan. Perbuatan tersebut menjadi bahaya bila anak-anak yang menjadi target korbannya karena mereka masih polos dan mudah dipengaruhi oleh pelaku trafficking. Dalam segi hukumannya, Allah swt berfirman dalam QS al-Maidah/5:32 yaitu,

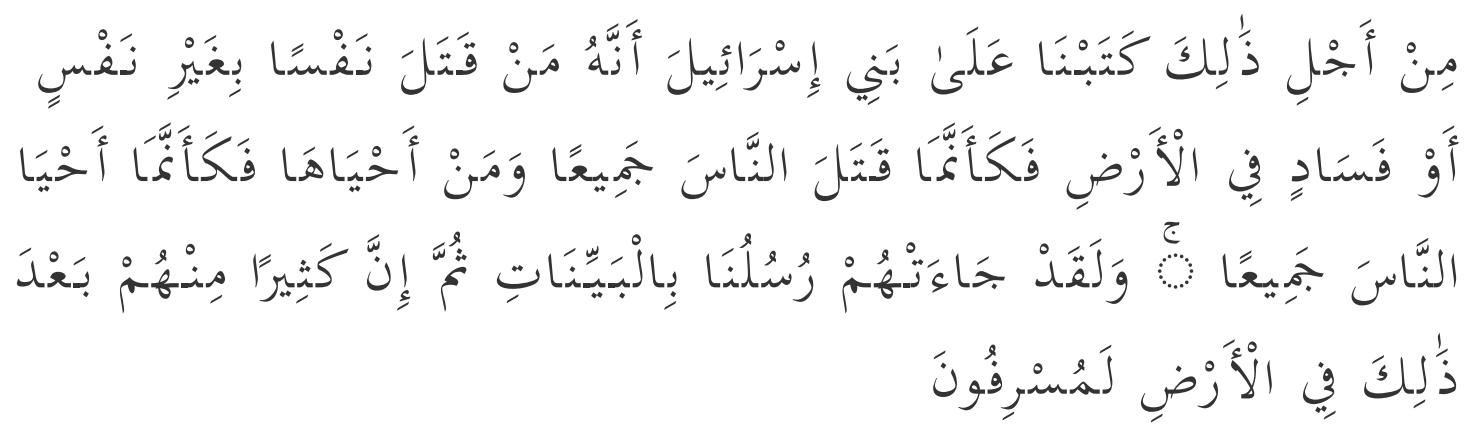

Terjemahnya:

"Oleh karena itu Kami tetapkan (suatu hukum) bagi Bani Israil, bahwa barangsiapa yang membunuh seorang manusia, bukan karena orang itu membunuh orang lain, atau bukan karena berbuat kerusakan dimuka bumi, maka seakan-akan dia telah membunuh semua manusia. Barangsiapa yang memelihara kehidupan seorang manusia, maka seakan-akan dia telah memelihara kehidupan semua manusia. Sesungguhnya Rasul kami telah datang

\footnotetext{
${ }^{57}$ Kementerian Agama, Al-Qur'an dan Terjemahnya (Jakarta: Sinergi Pustaka, 2012), h. 150.

${ }^{58}$ Mustofa Hasan, dan Beni Ahmad Saebani, Hukum Pidana Islam (Fiqh Jinayah): Dilengkap dengan Kajian Hukum Pidana Islam, h. 74.
} 
kepada mereka dengan (membawa) keterangan-keterangan yang jelas. Tetapi kemudian banyak diantara mereka setelah itu melampaui batas di bumi" ${ }^{59}$

\section{Jarimah ta'zir}

Jarimah ta'zir adalah hukuman yang belum ditetapkan syara' dan diserahkan sepenuhnya kepada ulil amri untuk menetapkannya. Jarimah ta'zir ini jenisnya beragam, nammun secara garis besar dapat dikelompokkan kepada empat kelompok, yaitu:

a. Hukuman ta'zir yang mengenai badan, seperti hukuman mati dan jilid (dera),

b. Hukuman yang berkaitan dengan kemerdekaan seseorang, seperti hukuman penjara dan pengasingan,

c. Hukuman ta'zir yang berkaitan dengan harta, seperti denda, penyitaan atau perampasan harta, dan penghacuran barang,

d. Hukuman-hukuman lain yang ditentukan oleh ulil amri demi kemaslahatan umum. $^{60}$

Dalam hal, perdagangan anak merupakan salah satu kejahatan kontemporer atau jenis perbudakan modern. Dibutuhkan suatu regulasi dan ketegasan oleh pemerintah atau ulil amri dengan tujuan memberikan pengawasan dan sanksi yang berat terhadap kejahatan perdagangan anak yang sangat meresahkan di masyarakat. Perdagangan dibuthkan perhatian yang seius dari semua pihak bai dari pemerintah, lembaga penegak hukum, lingkungan dan masyarakat dan terutama orangtua untuk bersam-sama mencegah dan melaporkan apabila terdapat peristiwa perdagangan anak.

Maka dengan peristiwa yang marak terjadi, Pemerintah Indonesia telah menerbitkan beberapa peraturan, yaitu sebagai berikut:

a. Undang-Undang No. 23 Tahun 2002 tentang Perlindungan Anak,

b. Undang-Undang Republik Indonesia No. 35 Tahun 2014 Tentang Perubahan Atas Undang-Undang No. 23 Tahun 2002 Tentang Perlindungan Anak.

c. Undang-Undang No. 21 Tahun 2007 tentang Pemberantasan Tindak Pidana Perdagangan Orang,

d. Keputusan Presiden Republik Indonesia Nomor 88 Tahun 2002 tentang Rencana Aksi Nasional Penghapusan Perdagangan (Trafficking) Perempuan dan Anak, dan

e. Keputusan Presiden Nomor 36 Tahun 1990 tentang Pengesahan Convention on the Rights of the Child (Konvensi tentang Hak-hak Anak).

\section{PENUTUP}

Penelitian ini memberikan pemahaman bahwa persolan tindak pidana perdagangan orang telah menarik perhatian banyak negara di berbagai dunia termasuk PBB. Perserikatan Bangsa-Bangsa (PBB) telah berusaha melakukan pencegahan dan pemberantasan terhadap perdagangan orang dengan mengeluarkan Protokol PBB untuk

\footnotetext{
${ }^{59}$ Kementerian Agama, Al-Qur'an dan Terjemahnya, h. 149-150

${ }^{60}$ Ahmad Wardi Muslich, Hukum Pidana Islam (Jakarta: Sinar Grafika, 2005) h. 258.
} 
mencegah, pemberantasan, dan menghukum perdagangan orang khususnya perempuan dan anak-anak. PBB juga telah mengeluarkan Konvensi PBB untuk melawan organisasi kejahatan lintas batas perdagangan orang.

Saat ini, perdagangan orang telah meluas, baik dalam bentuk jaringan kejahatan terorganisasi maupun tidak terorganisasi. Perdagangan orang juga menggunakan berbagai modus operandi yang berbeda-beda dengan lokasi di dalam dan di luar negeri. Kegiatan perdagangan orang terutama anak-anak makin marak berkembang karena kegiatan ini mampu memberikan keuntungan finansial yang sangat besar bagi pelakunya sehingga menjadi ancaman yang berbahaya bagi masyarakat di desa maupun di kota.

Kejahatan perdagangan manusia terutama perempuan dana anak berkembang karena adanya berbagai faktor pendorong, satu diantaranya yaitu faktor kemiskinan. Masyarakat miskin yang berada di daerah-daerah terpencil dijanjikan pekerjaan yang gajinya besar mendorong anak-anak tersebut terdorong untuk mengikuti ajakan dari para pelaku. Kondisi tingkat kemiskinan tersebut semakin mudah untuk dipengaruhi dika dibarengi dengan tingkat pendidikan yang rendah. Masyarakat tidak memiliki pengetahuan yang cukup untuk menganalisis ajakan dari para pelaku yang menawarkan gaji yang besar jika tingkat pendidikan yang dimiliki oleh seseorang tersebut tidak ada.

Selain itu, adanya pola hidup serba instan dan konsumtif, yaitu suatu pola hidup yang ingin cepat mendapatkan kekayaan dengan jalan yang cepat dan dengan kerja yang tidak berat. Kondisi pola hidup instan ini akan semakin mudah terpengaruh, apabila dibarengi dengan pola konsumtif terhadap pemenuhan semua kebutuhan dengan cepat. Saat ini, gejalanya bukan merupakan fenomena sosial biasa yang disebabkan oleh faktor kemiskinan dan ketertinggalan di bidang pendidikan semata, tetapi sudah menjadi fenomena pelanggarna hukum dan pelanggaran terhadap hak asasi manusia sebagai akibat dari adanya praktik tindak kejahatan yang dilakukan, baik secara perorangan maupun jejaring sindikat dengan maksud untuk mengeksploitasi korban demi keuntungan pelaku dan jaringannya. 


\section{DAFTAR PUSTAKA}

Aviandar, Distia, dkk, Analisis Situasi Hak Anak untuk Isu-isu Tertentu Yogyakarta: Yayasan Sekretariat Anak Merdeka Indonesia, 2010.

Dasgupta, Abhijit, dkk, Ketika Mereka Dijual: Perdagangan Perempuan dan Anak di 15 Propinsi di Indonesia Jakarta: ICMC Indonesia dan ACILS, 2006.

Fauzi, Niki Alma Febriana, Islam dan Human Trafficking: Upaya Nabi dalam Melawan Praktik Human Trafficking pada Masa Awal Islam. Muwazah, Jurnal Kajian Gender, Vol 9, No. 2 Desember 2017. Pusat Studi Gender dan Anak (PSGA) LP2M, IAIN Pekalongan, h. 103.

Gultom, Maidin, Perlindungan Hukum Terhadap Anak dan Perempuan Bandung: PT Refika Aditama, 2012.

Harefa, Beniharmoni, Kapita Selekta Perlindungan Hukum Bagi Anak (Ed. I; Cet. I; Yogyakarta: Deepublish, 2016.

Hasan, Hamzah, Kejahatan Kesusilaan Perspektif Hukum Pidana Islam Makassar: Alauddin University Press, 2012.

Hasan, Mustofa, dan Beni Ahmad Saebani, Hukum Pidana Islam (Fiqh Jinayah): Dilengkap dengan Kajian Hukum Pidana Islam Bandung: Pustaka Setia, 2013.

Hilali, Syaikh Salim bin 'Ied al-, Bahjatun Nazhirin Syarh Riyadhish Shalihin, terj. M. Abdul Ghoffar, Syarah Riyadhush Shalihin Jilid I, Jakarta: Pustaka Imam Syafi'i, 2012.

Kementerian Agama, Al-Qur'an dan Terjemahnya (Jakarta: Sinergi Pustaka, 2012.

Kodir, Faqihuddin Abdul, dkk, Fiqh Anti Trafficking: Jawaban atas Berbagai Kasus Kejahatan Perdagangan Manusia dalam Perspektif Hukum Islam (Bandung: Fahmina Institute, 2006.

Marlina dan Azmiati Zuliah, Hak Restitusi terhadap Koran Tindak Pidana Perdagangan Orang Bandung: Refika Aditama, 2015.

Mawia, Muhammad Ahmad Jadul, dkk, Qashash al-Qur'an, terj. Abdurrahman Assegaf, Kisah-kisah Al-Qur'an, Jakarta: Zaman, 2009.

Mufidah Ch, Mengapa Mereka Diperdagangkan ?: Membongkar Kejahatan Traficking dalam Perspektif Islam, Hukum, dan Gender Malang: UIN-Maliki Press, 2011.

Muslich, Ahmad Wardi, Hukum Pidana Islam Jakarta: Sinar Grafika, 2005.

Nuraeny, Henny, Tindak Pidana Perdagangan Orang: Kebijakan Hukum Pidana dan Pencegahannya, Jakarta: Sinar Grafika, 2011.

Nurhamidah, Buku Saku Pencegahan Perdagangan Anak: Lindungi Kami dari Jerat Perdagangan Anak Jakarta: Yayasan KKSP- Pusat Pendidikan dan Informasi Hak Anak, 2014.

Rosenberg, Ruth, Dkk, Perdagangan Perempuan dan Anak di Indonesia Jakarta: International Catholic Migration Commission (ICMC) dan American Center for International Labor Solidarity (ACILS), 2003.

Santoso, Topo, Membumikan Hukum Pidana Islam: Penegakan Syari'at dalam Wacana dan Agenda, Jakarta: Gema Insani Press, 2003. 
Saraswati, Rika, Hukum Perlindungan Anak di Indoesia Cet. II; Bandung: Citra Aditya Bakti, 2015.

Shihab, M. Quraish, Tafsir Al-Misbah: Pesan, Kesan, dan Keserasian Al-Qur'an, Vol. VII; Jakarta: Lentera Hati, 2002.

Tim Redaksi, Pasal 1 Undang-Undang No. 21 Tahun 2007 tentang Perdagangan Orang (Bandung: Citra Umbara, 2007. 